\title{
HEALTHY DIETARY PRACTICES AMONG BLACK SOUTH AFRICAN UNIVERSITY \\ STUDENTS
}

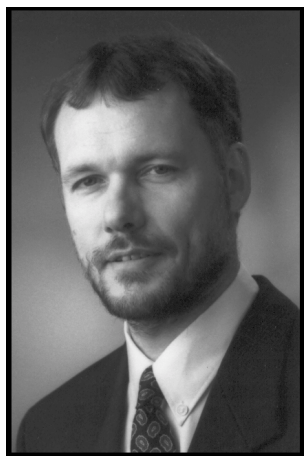

Prof. Karl Peltzer

Health Behaviour Research Unit, University of the North

\section{OPSOMMING}

Die doel van die navorsing was om vyf gesonde dieet gedragstyle van swart Suid-Afrikaanse studente na te vors. Die steekproef het bestaan uit 370 (46.7\%) manstudente en 423 (53\%) vroulike studente in die ouderdomsgroep 18 tot 25 jaar (gemiddelde ouderdom 21.0 jaar en standaardafwyking 3.48 jaar). Die resultate dui daarop dat die insidensie van die gesonde dieetgewoontes baie laag was. Beduidende verskille is ten opsigte van die volgende faktore bevind: geslag, dieetstatus, gesonde gelowe oor dieet, interne lokus van kontrole en risiko bewustheid maar nie vir ouderdom, gewig, residensiële omgewing, sosio-ekonomiese status en gesondheid nie. Logistieke regressie ten opsigte van gesondheidsgelowe, dieet status, geslag en kennis was slegs ten opsigte van enkele dieetgewoontes beduidende voorspellers. Ter samevatting kan gesê word dat die resultate insig gebring het ten opsigte van gesonde dieetpraktyke en die faktore wat daarin ' $n$ rol speel en die praktiese implikasies vir die bevordering van gesonde dieet.

\begin{abstract}
The aim of the study was to investigate five healthy dietary behaviours among black South African University students. The sample consisted of 370 (46.7\%) males and $423(53.3 \%)$ females in the age range of 18 to 25 years ( $M$ age 21.0 years, $S D=3.48$ ). Results indicate that the incidence of these healthy dietary habits was low. Significant differences with healthy dietary habits were identified for gender, dieting status, dietary health beliefs, internal health locus of control, and risk awareness, but not for age, weight, residential background, socioeconomic status, and health value. Logistic regression with health beliefs, dieting status, gender and knowledge were only significant predictors for a few healthy dietary habits. In conclusion, results give insights into dietary health behavior practices and the factors that influence them, which have practical implications for dietary health promotion.
\end{abstract}

\section{INTRODUCTION}

Chronic diseases of lifestyle were responsible for $24.5 \%$ of all deaths of all South Africans and 28.5\% of those aged 35-64 years (Bradshaw, Bourne, Schneider \& Sayed, 1995). The major causes of death contributing to these figures were cerebrovascular diseases ( $7.2 \%$ of all deaths) and ischaemic heart disease ( $8.7 \%$ of all deaths). Five point five million South Africans suffered from hypertension and had pressure above 140/90 $\mathrm{mmHg}$. The largest group was Blacks (3.0 million). For hypercholesterolaemia and raised low-density lipoprotein cholesterol levels, 4.8 million and 3.1 million South Africans respectively had an increased risk for ischaemic heart disease, Blacks having the lowest levels. Overall 4.88 million South Africans smoked, the largest group of smokers be- 
ing Black males (2.6 million) (Steyn, Fourie, \& Bradshaw, 1992:228f.).

Hypertension has a high prevalence in all language groups in South Africa (Edwards 1992:105); in a Black community in the Cape $(9.2 \%$ males and $12.9 \%$ females) (Steyn, Fourie, Lombard, Katzenellenbogen, Bourne \& Jooste, 1996:758), in urban Zulus 25\% and rural Zulus 9.4\%, (Seedat, Seedat \& Hackland, 1982:256); and 44\% of female Black (Indian 22\%, Whites 18\%) South Africans are obese (Walker, 1995:289). Obesity is a risk factor for the development of hypertension (Rhoades \& Pflanzer, 1992:684).

The WHO expects that by the year 2000 cardiovascular diseases will account for $15-25 \%$ of all death in developing countries. They emphasise the need for programmes of prevention to inhibit the entrenchment and spread of diseases related to unhealthy lifestyles in communities of developing countries (World Health Organisation, 1990:3ff.).

While the full etiology of any of these diseases has yet to be understood, behavioural factors such as tobacco use, exercise, diet, alcohol consumption and preventive health checks are strongly implicated as risk factors (Steptoe \& Wardle, 1992:486). Overconsumption of dietary fats, sugar and salt, and lack of fiber in the diet may lead to a number of chronic diseases including coronary heart disease and some cancers (Furie \& Steyn, 1995). Steyn, Langenhoven, Joubert, Chalton, Benadé and Rossouw (1990:63) indicate the influence of dietary factors in serum cholesterol values among the coloured population of the Cape Peninsula in South Africa. Rhoades and Pflanzer (1992:684) note that dietary factors that contribute to hypertension include high sodium intake, saturated fat intake, high cholesterol intake and deficiences in certain metal irons $(\mathrm{K}+, \mathrm{Ca} 2+, \mathrm{Mg} 2+)$.

Dietary behaviour may be mediated by economic and physical availability of food, its taste, beliefs concerning its health costs and benefits, and more generalised cognitive schema (Axelson \& Brinberg, 1989:5ff.). Bennett, Moore, Smith, Murphy and Smith (1994:41) found that the consumption of healthier foods was greatest among respondents with higher internal locus of control and value for health scores, while consumption of less healthy food items was higher amongst those with low value for health and high chance locus of control.

Knowledge about behaviour-health links (or risk awareness) is an important factor in an informed choice concerning healthy life-style. For instance, the reduction of smoking over the past 20 years in the Western world can be attributed to the growing awareness of the serious health risks such as lung cancer posed by tobacco use (Walker, 1995:77).

Another factor linked with risk awareness is belief of attitude. Various studies have shown that the perceived advantages of certain health behaviours are associated with the actual practice of such behaviours (Cody \& Lee, 1990:373).

The purpose of this study was to determine the prevalence of healthy dietary behaviour among black South African university students, to measure the power of the locus of control and value for health scales for predicting healthy dietary habits, and to assess attitudes of health benefits, risk awareness, and sociodemographic variables in relation to healthy diet patterns.

\section{METHODS}

\section{Sample and procedure}

The sample included 793 Black University students from non-health courses chosen from randomly selected classes from the University of the North, South Africa. The sample consisted of 370 (46.7\%) males and $423(53.3 \%)$ females in the age range of 18 to 25 years (M age 21.0 years, $S D=3.48$ ). Twenty-four percent of the students studied in the 
Faculty of Mathematics and Natural Sciences, 46.9\% in Management Sciences, and 28.4\% in Arts and Social Sciences. Most came from a self-rated not very well-off (within the 25-50\% range for your country in terms of wealth) $(45.5 \%)$ or quite poor (within the lowest $25 \%$ in your country in terms of wealth) (24.1\%) economic background.

Data were collected by a self-administered questionnaire in a class room situation after informed consent had been obtained. Participants were assured of complete anonymity.

\section{Measures}

The Health and Behaviour Survey (developed by Steptoe \& Wardle, 1996:49-73) was designed as a broad survey of health-related behaviours and beliefs. Each individual area is addressed by only a limited number of items. The following dietary behaviours were assessed: (a) frequency of consumption of red meat (daily, 2-3 times a week, once a week, less than once a week, never); b) frequency of consumption of fruit (daily, 2-3 times a week, once a week, less than once a week, never); c) addition of salt to food (usually, sometimes, occasionally, never); d) trying to avoid fat and cholesterol (yes, no); and e) trying to eat fiber (yes, no). The fiber and fat items were each followed by an openended question asking what foods the individual either avoided or ate. Ratings were also made of perceived body size (rated from very fat to very thin). Weight loss practices were recorded by using two items: "Are you trying to lose weight?" and "Are you on a diet?" For this sample Cronbach alpha and the split-half reliability coefficients for the 'dietary behaviour scale' was .70 and .67 respectively.

Attitudes towards healthy dietary practices were recorded by asking participants to rate, on a scale from 1 to 10, how important they thought each of the following dietary practices are: a) avoiding animal fat, b) eating fiber, c) eating fruit, d) avoiding salt, and e) eating breakfast. For this sample Cronbach alpha and the split-half reliability coefficients for the 'attitudes towards healthy dietary practices scale' was .68 and .65 respectively.

Knowledge was assessed by presenting the participants with a matrix of health problems related to lifestyle factors. Participants were asked to tick the appropriate box if they believed that a health problem was associated with that factor (Wardle, Steptoe, Bellisle, Davou, Reschke \& Lappalainen, 1997:444f.). Only two items of knowledge of diet and disease relationships are discussed here: the awarenes of the links between animal fat and heart disease, and between obesity and high blood pressure.

Data were also collected using additional instruments that assess factors shown to be important to health behaviour in research in health psychology. These included the Multidimensional Health Locus of Control Scale (MHLOC) (Wallston, Wallston \& DeVellis, 1978:160) and the Health as a Value Scale (Lau \& Ware, 1981:1148f.). The MHLOC assesses people's perceptions of how their health is controlled by their own behaviour (internally), by powerful others or by chance (that is, external factors over which they have little or no control). Cronbach alpha and the split-half reliability coefficients for the 'Multidimensional Health Locus of Control Scale' 'attitudes towards healthy dietary practices scale' was .76 and .69 for this sample respectively. Cronbach alpha and the split-half reliability coefficients for the 'Health as a Value Scale' was .71 and .68 for this sample respectively.

Data on age, marital status, number of children, height, and weight were also collected. Self-reported height and weight was used to calculate body mass index [weight (kg)/height (m)2]

The instrument was pre-tested on 15 male and 15 female students, who did not form part of the final sample. 
Table 1: Healthy dietary practices by gender

\begin{tabular}{|l|l|l|l|}
\hline Healthy diet behaviour & Women (\%) & Men (\%) & $X^{2}$ \\
\hline Try to avoid fat and cholesterol & 51 & 37 & $15.933^{\ldots \ldots}$ \\
\hline Try to eat fiber & 36 & 36 & .402 \\
\hline Eat fruit daily & 34 & 24 & 25.684 \\
\hline Limit red meat & 79 & 81 & 1.037 \\
\hline Limit salt & 47 & 46 & .801 \\
\hline
\end{tabular}

\section{RESULTS}

The prevalence of the individual healthy dietary practices for men and women is shown in Table 1. More women than men reported that they tried to avoid fat and cholesterol and the gender difference was significant. Likewise, significantly more women than men reported to eat fruit daily. In relation to fruit consumption, the healthy practice is defined as eating fruit daily (WHO, 1990:24ff.). Generally, daily fruit consumption was a minority practice for men (24\%), but somewhat higher for women (34\%). For adding salt to the food, the unhealthy practice is defined as responding usually to this question, whereas any of the other responses (sometimes, occasionally, or never) are categorised as healthy. The fifth dietary behaviour recorded was red meat consumption, where the healthy practice is defined as eating meat less often than daily (including never). Never eating red meat - sometimes used as a criterion for vegetarianism - was similarly common among men and women (10\% vs. $8 \%)$.

On an open question on what fatty and cholesterol food the participants avoided and what high fiber food they tried to eat, they listed the following types of food that contain fat and cholesterol, in descending order of importance: fried food, fatty meat (e.g. mutton, pork), butter, margarine, red meat, food rich in starch (e.g. potatoes, bread, rice), and chocolate, and they listed also the types of foods that are high in fiber: food rich in starch (e.g. potatoes, bread, rice), cereals, oats, vegetables, fruit, and other.

\section{Weight, weight control, and dietary practices}

About 14 percent (14.4\%) of women and $15.9 \%$ of men reported weights that translated into a BMI over $25(X 2=n s)$, and $8.7 \%$ of women and $8.1 \%$ of men reached a BMI over $30(\mathrm{X} 2=\mathrm{ns})$. Similarly, $21 \%$ of women and $9.7 \%$ of men described themselves as overweight $(\mathrm{X} 2=13.452, \mathrm{p}<.001)$.

Dietary practices in relation to dieting status are shown in Table 2.

Table 2: Percentages of dieters and non dieters endorsing each current dietary practice among women and men

\begin{tabular}{|c|c|c|c|c|c|}
\hline \multicolumn{6}{|l|}{ Dietary practice } \\
\hline Dietary status & $\begin{array}{l}\text { Awoid fat } \\
(\%)\end{array}$ & $\begin{array}{l}\text { Eat fiber } \\
(\%)\end{array}$ & $\begin{array}{l}\text { Eat fruit } \\
\text { daily }(\%)\end{array}$ & $\begin{array}{l}\text { Limit red } \\
\text { meat }(\%)\end{array}$ & $\begin{array}{l}\text { Limit salt } \\
(\%)\end{array}$ \\
\hline \multicolumn{6}{|l|}{ Women } \\
\hline Dieting $(n=94)$ & 63 & 31 & 42 & 72 & 56 \\
\hline Not dieting ( $n=329$ ) & 48 & 36 & 33 & 81 & 45 \\
\hline \multicolumn{6}{|l|}{ Men } \\
\hline Dieting $(\mathrm{n}=31)$ & 57 & 30 & 35 & 73 & 52 \\
\hline Not dieting ( $n=339$ ) & 35 & 38 & 24 & 81 & 45 \\
\hline
\end{tabular}

Pearson's Chi-Square showed among women that dieters were more likely to be avoiding fat $(\mathrm{X} 2=6.235 ; \mathrm{p}<.013)$ and limiting salt $(\mathrm{X} 2=3.872$; $\mathrm{p}<.049$ ). Among men, dieters were only more likely to be avoiding fat $(\mathrm{X} 2=5.554 ; \mathrm{p}<.018)$. There were no significant effects of dieting on eating fiber, eating fruit daily and limiting red meat for men or women.

\section{Nutrition knowledge and behaviour}

For two of the risk factors, avoiding fat and being overweight, indicators for risk awareness had been recorded. Overall, $55.7 \%$ of the participants were aware of the animal fat-heart disease association, and $62.3 \%$ were aware of the being overweighthigh blood pressure association. There were no significant gender differences between males and females in knowledge of fat and heart disease and overweight and high blood pressure.

There was no significant association between risk awareness and behaviour, i.e. knowledge of animal fat-heart disease association and avoidance of eating animal fat and cholesterol as well as knowl- 
edge of obesity-high blood pressure association and trying (including dieting) to lose weight.

\section{Dietary behaviour, health locus of control, and health value}

To produce a more quantifiable index, and to simplify the presentation, a healthy diet index score was calculated including (1) eat fruit daily, (2) avoid fat, (3) eat fiber, (4) limit red meat, and (5) limit salt. For each of the healthy dietary behaviours one score was given for the healthy practice (range from $0-5)$.

Women had a significantly higher healthy diet index than men had $(X 2=42.489, \mathrm{p}<.001)$. Age, weight, residential background and economic status were not significantly associated with the healthy diet index.

Furthermore, the health diet index was significantly positively associated with internal health locus of control $(\mathrm{r}=.098, \mathrm{p}<.01)$ but not with chance locus ( $\mathrm{r}=-.73$, ns) and health value $\mathrm{r}=.033$, ns). In particular, eating fiber $(r=.116, p<.001)$ and avoiding fat $(\mathrm{r}=.077, \mathrm{~ns})$ were significantly associated with internal health locus whereas eating fruit $(\mathrm{r}=-.017$, $\mathrm{ns})$, limiting salt $(\mathrm{r}=.019)$ and limiting red meat ( $r=.013$, ns) was not (see Table 3).

Table 3: Pearson correlation between healthy dietary behaviour and health locus and helath value

\begin{tabular}{|l|l|l|l|}
\hline \multirow{2}{*}{$\begin{array}{l}\text { Healthy dietary } \\
\text { behaviour }\end{array}$} & Intemal locus & Chance locus & Health value \\
\cline { 2 - 4 } & $r$ & $r$ & $r$ \\
\hline Awoiding fat & $.077^{*}$ & $-.076^{*}$ & .041 \\
\hline Eating fiber & $.116^{+* *}$ & -.060 & .007 \\
\hline Eating fruit & -.017 & .043 & .008 \\
\hline Limiting salt & .019 & $-.80^{*}$ & .047 \\
\hline Limiting red meat & .013 & .026 & -.021 \\
\hline Healthy diet index & $.098^{*}$ & -.073 & .033 \\
\hline
\end{tabular}

\section{Dietary health beliefs and behaviour}

Beliefs about the importance of selected dietary practices were recorded on a scale from 1 (of very low importance) to 10 (of very great importance). Most of the dietary practices were rated at least 6 (see Table 4).
Table 4: Gender differences in ratings of belief in the importance of dietary practices

\begin{tabular}{|l|l|l|l|l|l|l|l|}
\hline \multirow{2}{*}{ Belief } & Women & Men & \multicolumn{3}{l|}{ Gender difference } \\
\cline { 2 - 8 } & M & $\mathrm{SD}$ & M & $S \mathrm{D}$ & $t$ & df & $p$ \\
\hline $\begin{array}{l}\text { Not eating too } \\
\text { much animal fat }\end{array}$ & 6.45 & 3.24 & 6.08 & 2.93 & -1.663 & 781 & .097 \\
\hline $\begin{array}{l}\text { Eating enough } \\
\text { fiber }\end{array}$ & 7.31 & 2.67 & 7.04 & 2.63 & -1.434 & 775 & .152 \\
\hline $\begin{array}{l}\text { Eating enough of } \\
\text { fruit }\end{array}$ & 8.47 & 2.34 & 8.15 & 2.42 & -1.058 & 784 & .064 \\
\hline $\begin{array}{l}\text { Not adding too } \\
\text { much salt }\end{array}$ & 7.42 & 3.06 & 6.63 & 3.15 & -3.520 & 766 & .000 \\
\hline $\begin{array}{l}\text { Eating breakfast } \\
\text { almost every day }\end{array}$ & 7.82 & 2.72 & 7.23 & 3.09 & -2.840 & 772 & .005 \\
\hline
\end{tabular}

The men believed that certain items were less important about the health benefits of each of the dietary factors than women and particularly so in relation to limiting salt intake and having breakfast. The highest mean health benefits ratings were given for "eating enough fruit" and yet eating fruits daily had a very low prevalence in this sample (29\%). Lowest mean ratings were given for "not eating too much animal fat", which seem to correspond to a low rate of avoiding dietary fat (44\%).

The relationship between beliefs and behaviour was evaluated by computing the odds ratios for practicing each behaviour in relation to the belief rating. Sex was included in the analysis as it was shown to be related both to beliefs and behaviour. The results of the stepwise logistic regression, which included dieting and knowledge as additional independent variables, are shown in Table 5.

Table 5: Regression coefficients of health beliefs, gender, dieting, and knowledge as predictors of dietary behaviours

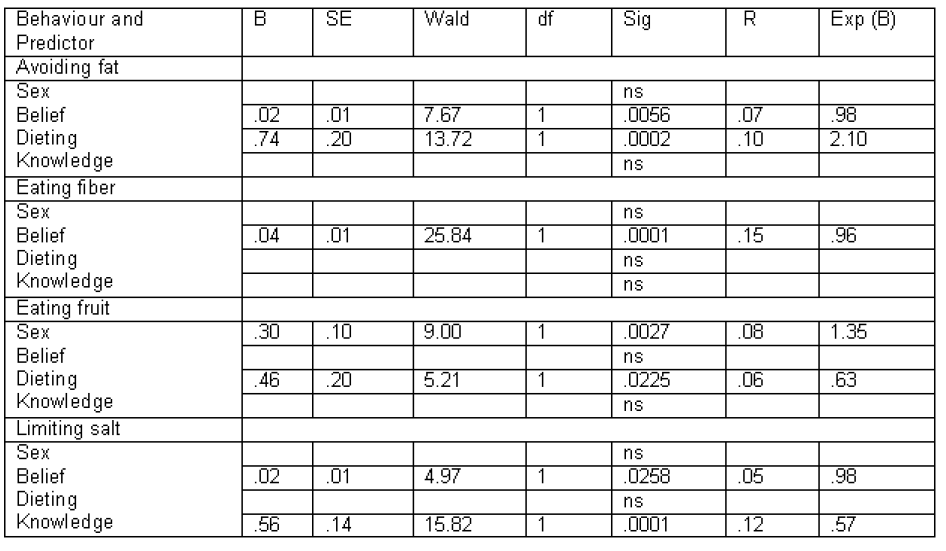

The dependent dichotomous variables were avoiding fat ('yes' was coded as ' 1 ' and 'no' as ' 0 '), eating fiber, eating fruit, and limiting salt.

Beliefs in the importance of "not eating too much animal fat" was a significant independent predic- 
tor for the actual behaviour of avoiding dietary fat, "to eat enough fiber" for eating high fiber foods, and "limiting salt" for limited salt intake. Sex was a significant predictor for eating fruits, women ate more fruits than men. Dieting was predictive for avoiding fat and eating fruit. The risk awareness of a diet behaviour was only predictive in the case of limiting salt and not for the other three behaviours. Health locus of control and health value could not be identified as an independent significant predictor for any of the healthy diet behaviours.

\section{DISCUSSION}

The study found a low prevalence of five simple healthy dietary practices among this sample of young people, which is a cause for concern. Compared to European University students (e.g. Austria $52 \%$ or Spain $74 \%$ ), the prevalence of eating fruits was particularly low is this sample (29\%) (Wardle et al. 1997:445f.). This finding needs further investigation.

Generally women showed more healthy dietary practices than men did, which also conforms with European University students (ibid.:447). Although more women (22.2\%) were dieting than men (8.4\%) were, it did not have a significant influence on healthy diet behaviour. This was also found in other studies (ibid.:448).

Most healthy dietary practices were significantly associated with beliefs in the importance of diet for health and internal health locus of control, which conforms to what was found among European university students (ibid.:447). This may give support to a cognitive model of dietary health behaviour. On the other hand risk awareness (apart from limiting salt), and health value were not significantly associated with healthy diet behaviour. Other studies such as among European University students (ibid.:447) and in a representative sample in Britain (Bennett et al. 1994:41) also found a significant association between internal health locus, health value and healthy diet behaviour. This study could not identify internal health locus of control and health value as an independent predictor for any of the healthy diet habits. It may be that the health locus of control and health value measures have limitations in African settings, MacLachlan, Ager and Brown (1996:33) also reported a failure of the cross-cultural validity of the Health Locus of Control based on a study in Malawi.

The rate of overweight status in this sample of female black students is similar to that found among first entering students of the University of the North ( $6.5 \%$ obese, $18.2 \%$ overweight) by Steyn, Senekal, Brits, Alberts, Mashego and Nel (2000:146).

In conclusion, results give insights into dietary health behaviour practices and the factors that influence them, which have practical implications for dietary health promotion.

\section{Acknowledgement}

Andrew Steptoe is thanked for the research instrument and the University of the North for financially supporting the study.

\section{REFERENCES}

Axelson ML \& Brinberg D 1989: A socio-psychological perspective on food-related behaviour. New York: Springer Verlag.

Bennett P; Moore L; Smith A; Murphy S \& Smith C 1994: Health locus of control and value for health as predictors of dietary behaviour. Psychology \& Health, 1994:41-54.

Bradshaw D; Bourne DE; Schneider M \& Sayed R 1995: Mortality patterns of chronic diseases of life style in South Africa. (In: Furie, J \& Steyn, K eds. 1995: Chronic diseases of life style in South Africa. Cape Town: MRC Technical Reports, pp. 5-36).

Cody R \& Lee C 1990: Behaviours, beliefs, and intentions in skin cancer prevention. Journal of Behavioral Medicine, 13:373-389.

Edwards DJA 1992: The challenge of hypertension to 
South African health psychology: 1. The potential contribution of educational, cognitive and behavioural strategies to prevention and treatment. South African Journal of Psychology, 22:105-116.

Furie J \& Steyn K eds. 1995: Chronic diseases of life style in South Africa. Cape Town: MRC Technical Reports.

Lau RR \& Ware JEJR 1981: Refinements in the measurement of health-specific locus-of-control beliefs. Medical Care, 19:1147-1158.

MacLachlan M; Ager A \& Brown J 1996: Health Locus of Control in Malawi: a failure to support the cross-cultural validity of the HLOCQ. Psychology \& Health, 12:33-38.

Rhoades R \& Pflanzer R 1992: Human physiology. New York: Saunder College Publishing.

Seedat YK; Seedat, MA \& Hackland, DB 1982: Prevalence of hypertension in urban and rural Zulu. Journal of Epidemiology \& Community Health, 26:256-261. Steptoe A \& Wardle J 1992: Cognitive predictors of health behaviour in contrasting regions of Europe. British Journal of Clinical Psychology, 31:485-502.

Steptoe A \& Wardle J 1996: The European health and behaviour survey: the development of an international study in health psychology. Psychology \& Health, 11:49-73.

Steyn, K; Fourie, J \& Bradshaw, D 1992: The impact of chronic diseases of lifestyle and their major risk factors on mortality in South Africa. South African Medical Journal, 82:227-231.

Steyn K; Fourie J; Lombard C; Katzenellenbogen J; Bourne L \& Jooste P 1996: Hypertension in the black community of the Cape Peninsula, South Africa. East African Medical Journal, 73:758-763.

Steyn K; Langenhoven ML; Joubert G; Chalton DO; Benadé AJS \& Rossouw JE 1990: The relationship between dietary factors and serum cholesterol values in the coloured population of the Cape Peninsula. South African Medical Journal, 78:63-67.

Steyn NP; Senekal M; Brits S; Alberts M; Mashego T \& Nel JH 2000: Weight and health status of black female students. South African Medical Journal, 90:146-152 Walker ARP 1995: Epidemiology and health implications of obesity in Southern Africa (In: Furie J \& Steyn
K eds. 1995: Chronic diseases of life style in South Africa. Cape Town: MRC Technical Reports, pp. 73-86). Wallston KA; Wallston BS \& DeVellis R 1978: Development of the multi-dimensional health locus of control. Health Education Monographic, 6:160-170. Wardle J; Steptoe A; Bellisle F; Davou B; Reschke K \& Lappalainen R 1997: Healthy dietary practices among European students. Health Psychology, 16:443-450. World Health Organisation 1990: Diet, nutrition, and the prevention of chronic diseases. Geneva: Author. 